\title{
Purification and characterization of a novel thermoacidophilic and thermostable $\alpha$-mannosidase from the digestive fluid of oil palm weevil Rhynchophorus palmarum (Coleoptera: Curculionidae) larvae
}

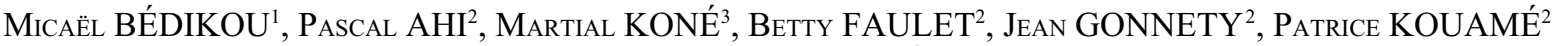 \\ and SÉBASTIEN NIAMKÉ*1,2 \\ ${ }^{1}$ Laboratoire de Biotechnologies, Filière Biochimie-Microbiologie de l'Unité de Formation et de Recherche en Biosciences \\ de l'Université de Cocody-Abidjan, 22 BP 582 Abidjan 22, Côte d'Ivoire \\ ${ }^{2}$ Laboratoire de Biochimie et Technologie des Aliments de l’Unité de Formation et de Recherche en Sciences et Technologie \\ des Aliments de l'Université d'Abobo-Adjamé, 02 BP 801 Abidjan 02, Côte d'Ivoire \\ ${ }^{3}$ Unité de Biotechnologie, Biocatalyse et Biorégulation, CNRS-UMR 6204, Laboratoire de Biochimie, Faculté des Sciences \\ et Techniques, 2 Rue de la Houssinière, BP 92208, F-44322 Nantes Cedex 3, France
}

Key words. $\alpha$-mannosidase, thermoacidophilic, thermostable, oil palm weevil, Rhynchophorus palmarum, Curculionidae

\begin{abstract}
An extracellular $\alpha$-mannosidase with unusual properties was purified from the digestive fluid of oil palm weevil (Rhynchophorus palmarum Linnaeus) larvae using ammonium sulphate saturation, size exclusion and anion-exchange chromatography. The enzyme named Rplt $\mathrm{M}$ is thermoacidophilic, thermostable and behaves like lysosomal $\alpha$-mannosidase (EC 3.2.1.24). The molecular weight, $\mathrm{K}_{\mathrm{m}}$ value, optimum reaction temperature and $\mathrm{pH}$ are $108-112 \mathrm{kDa}, 0.36 \mathrm{mM}, 65^{\circ} \mathrm{C}$ and 4.5 , respectively. $\mathrm{Zn}^{2+}$ enhanced whereas $\mathrm{Cu}^{2+}$, Sodium dodecyl sulphate, swainsonine and 1,4-dideoxy-1,4-iminomannitol strongly inhibited its hydrolytic activity. The enzyme was stable for $25 \mathrm{~min}$ at $65^{\circ} \mathrm{C}$ and retained $70 \%$ of its initial activity after $60 \mathrm{~min}$. At $70^{\circ} \mathrm{C}$, around $60 \%$ of this activity was conserved after $25 \mathrm{~min}$. RpltM retained more than $90 \%$ of its activity over a pH range of 4.2 to 5.0 and remained fully active in the presence of detergents such as nonidet P-40, triton X-100, polyoxyethylen-10-oleyl ether (up to 1\%, w/v), dithiothreitol and $\beta$-mercaptoethanol. The stability under these conditions is also better than that reported for other insect $\alpha$-mannosidases. Thus, Rplt $\mathrm{M}$ could be used as an important bioindustrial tool for removing mannose residues from oligosaccharides.
\end{abstract}

\section{INTRODUCTION}

$\alpha$-mannosidases are glycosyl hydrolases (GHs) that cleave specific $\alpha$-linked mannose residues. They fall into two distinct classes with different substrate specificities, intracellular locations, sizes, cation requirements, sensitivities to plant alkaloid inhibitors and amino acid sequence alignments (Moremen et al., 1994; Moremen, 2000).

The first group termed class I $\alpha$-mannosidases are located in the endoplasmic reticulum (ER) and Golgi complex and are strictly specific to $\alpha-1,2$ linked mannose residues of $\mathrm{Man}_{9} \mathrm{GlcNAc}_{2}$, converting this substrate to $\mathrm{Man}_{5} \mathrm{GlcNAc}_{2}$. Class I $\alpha$-mannosidases are sensitive to specific inhibitors such as kifunensine (Kif) and 1-deoxymannojirimycin (DMNJ) and belong to family 47 in the GHs classification (Henrissat \& Bairoch, 1996).

Class I mannosidases contrast with the more heterogeneous collection of processing and catabolic enzymes termed class II mannosidases that are present in the ER, Golgi, Lysosome and Cytosol. Golgi mannosidase II is a well known class II enzyme involved in N-glycan processing. This enzyme is specific to GlcNAcMan ${ }_{5} \mathrm{GlcNAc}_{2}$, cleaving the terminal $\alpha-1,3$ and $\alpha-1,6$-linked mannose residues from this substrate to produce GlcNAcMan ${ }_{3}$ Glc$\mathrm{NAc}_{2}$ (Henrissat \& Bairoch, 1993; Shah et al., 2008).

Lysosomal and cytosolic $\alpha$-mannosidases (EC 3.2.1.24) belong also to class II mannosidases and are involved in the catabolism of the Asn-linked carbohydrates of glycoproteins. These enzymes display a broad substrate specificity by cleaving all three $\alpha-1,2 ; \alpha-1,3$ and $\alpha-1,6$ mannosyl linkages in high mannose and hybrid type glycans (Howard et al., 1997). A deficiency of the first enzyme leads to the genetic lysosomal disease $\alpha$-mannosidosis (Thomas et al., 2001; Heikinheimo et al., 2003).

Class II $\alpha$-mannosidases belong to GHs family 38 (Henrissat \& Bairoch, 1993) and are sensitive to the azafuranose analogues of mannose, swainsonine $(\mathrm{Sw})$ and 1,4-dideoxyiminomannitol (DIM) (Cenci di Bello et al., 1989; Shah et al., 2008).

The mannosidases are enzymes of great importance because of their physiological role and wide application. $\alpha$-mannosidases are key enzymes, widespread in nature and found in all eukaryotes from yeast to man (Liao et al., 1996; Tatara et al., 2003; Ahi et al., 2007; Tremblay et al., 2007). They are involved in the processing of newly formed N-glycans by modifying oligosaccharide structures linked to appropriate asparagine residues of proteins

\footnotetext{
* Corresponding author; e-mail: niamkes@yahoo.fr
} 
and thus influence their properties and bioactivity (Varki, 1993; Moremen, 2000; Akama et al., 2006). In the pharmaceutical industry, $\alpha$-mannosidases are currently used for treatment of mannosidosis, a congenital disorder of glycosides (CDG), by enzyme replacement therapy (Sun et al., 1999; Hirsch et al., 2003). Furthermore, it is suggested that $\alpha$-mannosidases be used synergistically with $\mathrm{N}$-acetyl- $\beta$-hexosaminidase in the medical treatment of fungal diseases (Giordani et al., 1991). In vitro, $\alpha$-mannosidases are useful tools for enzymatic analysis of high mannose oligosaccharide structures (Maruyama et al., 1994; Misaki et al., 2003) and for oligosaccharide synthesis (Michalski et al., 1990; Athanasopoulos et al., 2004).

Although $\alpha$-mannosidases ( $\alpha$-mannoside mannohydrolase EC 3.2.1.24) are widely distributed, and have been isolated from plants, fungi and animal tissues (Kornfeld \& Kornfeld, 1985), the majority are identified as mesophilic enzymes. Thus, this first record of thermophilic $\alpha$-mannosidase activity in an insect attracted our attention.

This paper describes the purification and characterization of $\alpha$-mannosidase Rplt $\mathrm{M}$ from Rhynchophorus palmarum larvae and explores its potential use in biotechnological oligomannosyl degradation.

\section{MATERIAL AND METHODS}

\section{Enzymatic source and preparation of crude extract}

Oil palm weevil (Rhynchophorus palmarum Linnaeus) larvae were collected locally in Côte d'Ivoire from their host trees (oil palm, Elaeis guineensis Jacquin). The digestive fluid was collected with a syringe, filtered through cotton wool and then centrifuged at $10,000 \times \mathrm{g}$ for $30 \mathrm{~min}$ at $4^{\circ} \mathrm{C}$. The supernatant constituted the crude extract.

\section{Chemicals}

Para-nitrophenyl- $\alpha-\mathrm{D}-$ Mannopyranoside ( $p$ NP- $\alpha-\mathrm{Man})$ and the other synthetic aryl-glycoside substrates, Mannobioses (2-O- $\alpha$-D-mannopyranosyl-D-mannopyranoside, 3-O- $\alpha-\mathrm{D}-$ mannopyranosyl-D-mannopyranoside and 6-O- $\alpha-\mathrm{D}-\mathrm{manno}-$ pyranosyl-D-mannopyranoside), swainsonine (Sw), 1,4-dideoxy-1,4-iminomannitol (DIM) and 1-deoxymannojirimycin (DMNJ) were purchased from Sigma-Aldrich. D $(+)$ Mannose was purchased from Panreac Quimica, Kifunensine (Kitasatosporia kifunense) (Kif) from Calbiochem, Sephacryl S-100 HR, Sephacryl S-200 HR and DEAE-Sepharose Fast Flow from Pharmacia-LKB Biotech, Bovine Serum Albumin (BSA) from Fluka Biochemika, and Silicate gel $60 \mathrm{~F}_{254}$ for thinlayer chromatography (TLC) from Merck. Protein Standards used for molecular mass determination on polyacrylamide gel electrophoresis were provided by Bio-Rad. All other chemicals and reagents were of analytical grade.

\section{Purification procedure}

All steps in the purification procedure were performed at $4{ }^{\circ} \mathrm{C}$. The crude extract was submitted to ammonium sulphate precipitation at $80 \%$ saturation. After centrifugation at $10,000 \mathrm{~g}$ for 30 min, the precipitate was dissolved in $1 \mathrm{ml}$ of $20 \mathrm{mM}$ acetate buffer $(\mathrm{pH} 4.5)$ and the resulting solution loaded onto a Sephacryl S-100 HR column (capacity, $1.5 \mathrm{~cm} \times 67 \mathrm{~cm}$; flow rate, $0.2 \mathrm{ml} / \mathrm{min}$; fractions, $1 \mathrm{ml}$ ) previously equilibrated with the same buffer. The active fractions were pooled and adsorbed on a DEAE-Sepharose Fast Flow column $(2.5 \mathrm{~cm} \times 4.5 \mathrm{~cm})$ equilibrated with $20 \mathrm{mM}$ acetate buffer (pH 4.5). After washing the column (flow rate, $3 \mathrm{ml} / \mathrm{min}$; fractions, $1 \mathrm{ml}$ ) with the same buffer, a $40 \mathrm{ml}$ increasing discontinuous gradient $(0 ; 0.1 ; 0.15$; 0.4 and $1.0 \mathrm{M}$ ) of $\mathrm{NaCl}$ dissolved in $20 \mathrm{mM}$ acetate buffer $(\mathrm{pH}$ 4.5) was applied to the column. Finally, the active fractions were pooled, dialyzed against $20 \mathrm{mM}$ acetate buffer $(\mathrm{pH} 4.5)$ and stored at $4^{\circ} \mathrm{C}$.

\section{Enzyme assay}

The $\alpha$-mannosidase assay was performed by incubating 100 $\mu 1$ of $p$ NP- $\alpha$-Man $(2.5 \mathrm{mM})$ in $100 \mathrm{mM}$ sodium acetate buffer (pH 4.5) with $50 \mu 1$ of the enzyme solution at $37^{\circ} \mathrm{C}$ for $20 \mathrm{~min}$. Reactions were stopped by adding $2 \mathrm{ml}$ of sodium carbonate $2 \%$ $(\mathrm{w} / \mathrm{v})$. The released para-nitrophenol $(p N \mathrm{~N})$ was quantified at $410 \mathrm{~nm}$. One unit of activity (UI) was defined as the amount of enzyme that hydrolyzes $1 \mu \mathrm{mol}$ of substrate per min under the assay conditions.

\section{Estimation of protein concentration}

Protein concentration was measured using the Folin ciocalteus method (Lowry et al., 1951). BSA was used as the standard protein.

\section{Determination of molecular mass}

The molecular mass of the $\alpha$-mannosidase was determined by sodium dodecyl sulphate-polyacrylamide gel $(7.5 \%, \mathrm{w} / \mathrm{v})$ electrophoresis (SDS-PAGE) under denaturing conditions (Laemmli, 1970). Just before running, samples (5 $\mu \mathrm{g})$ were incubated for $5 \mathrm{~min}$ at $100^{\circ} \mathrm{C}$ in SDS-PAGE sample buffer containing $\beta$-mercaptoethanol. Proteins were located on the gel using silver staining (Blum et al., 1987). Electrophoresis of the native enzyme was performed using essentially the same method, but without SDS and $\beta$-mercaptoethanol. The molecular mass of the native $\alpha$-mannosidase was estimated by gel filtration on a Sephacryl S-200 HR column (capacity, $0.8 \mathrm{~cm}$ $\times 35 \mathrm{~cm}$; flow rate, $0.2 \mathrm{ml} / \mathrm{min}$; fractions, $0.5 \mathrm{ml}$ ) equilibrated with $20 \mathrm{mM}$ acetate buffer ( $\mathrm{pH} 4.5$ ). The standard proteins (SIGMA) used for calibration were $\beta$-amylase from sweet potato $(206 \mathrm{kDa}), \mathrm{BSA}(66 \mathrm{kDa})$, ovalbumin from egg white (45 $\mathrm{kDa}$ ) and cellulase from Aspergillus niger (26 kDa). Blue dextran $(1000 \mathrm{kDa})$ and potassium ferricyanide $(0.33 \mathrm{kDa})$ were used to determine the void and the total volume, respectively.

\section{pH and temperature optima}

In these experiments, the $\mathrm{pH}$ values were determined at $25^{\circ} \mathrm{C}$. For determination of the optimum $\mathrm{pH}$, the $\alpha$-mannosidase activity was measured by performing the assays at $37^{\circ} \mathrm{C}$ and various $\mathrm{pH}$ values in the following $100 \mathrm{mM}$ buffer systems: sodium acetate buffer from $\mathrm{pH} 3.6$ to 5.5 ; sodium phosphate buffer from $\mathrm{pH} 5.6$ to 7.5 and sodium citrate buffer from $\mathrm{pH} 3.0$ to 6.0. For determining the optimum temperature, the incubations were performed at temperatures ranging from 30 to $80^{\circ} \mathrm{C}$.

\section{pH and temperature stabilities}

For the $\mathrm{pH}$ stability study, the enzyme solution was preincubated for $2 \mathrm{~h}$ at room temperature at various $\mathrm{pH}$ values between 3.0 to 7.5 (buffer systems above). After adjusting the mixture to $\mathrm{pH} 4.5$, the residual activity was measured under the assay conditions. The thermal denaturation of the $\alpha$-mannosidase $R p l t \mathrm{M}$ was investigated by preheating aliquots for $25 \mathrm{~min}$ at temperatures between 30 and $80^{\circ} \mathrm{C}$. For the thermal inactivation, experiments were performed at 37 and $65^{\circ} \mathrm{C}$ by pre-warming the enzyme solution for from 0 to 150 $\min$ in $100 \mathrm{mM}$ acetate buffer ( $\mathrm{pH} 4.5$ ). Aliquots were removed at different times and the residual activity measured at $37^{\circ} \mathrm{C}$. 

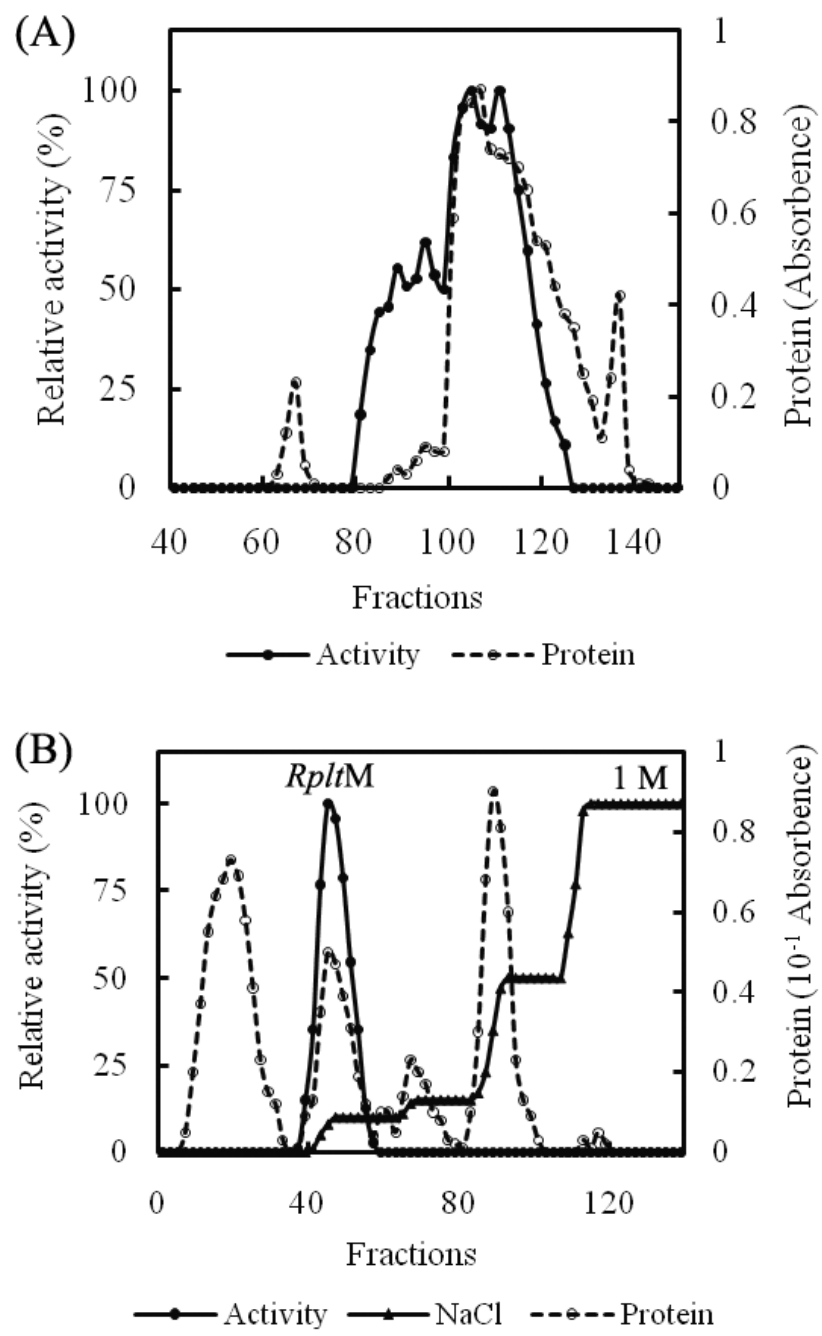

Fig. 1. Chromatographic profiles of $\alpha$-mannosidase Rplt $\mathrm{M}$ from the digestive fluid of oil palm weevil (Rhynchophorus palmarum) larvae. The enzyme activity was measured in $100 \mathrm{mM}$ sodium acetate buffer $\mathrm{pH} 4.5$ at $37^{\circ} \mathrm{C}$ using $p \mathrm{NP}-\alpha-$ Man as the substrate. (A) Gel filtration chromatography on a Sephacryl S-100 HR column. (B) Anion-exchange chromatography on a DEAE-Sepharose Fast Flow column. For further details, see "Material and methods".

\section{Effect of chemical agents}

Metal ions, detergents, reducing agents and specific inhibitors were mixed with the enzyme for $30 \mathrm{~min}$ at room temperature. Then, the $\alpha$-mannosidase activity was measured. The residual activity was expressed as a percentage of the control without the chemical agent.

\section{Substrate specificity and kinetic parameters determinations}

The study of substrate specificity was performed with a variety of synthetic substrates (para-nitrophenyl-glycosides, 2.5 $\mathrm{mM}$ ) incubated at $37^{\circ} \mathrm{C}$ for $20 \mathrm{~min}$, in $100 \mathrm{mM}$ sodium acetate buffer $(\mathrm{pH} 4.5)$. The reactions were stopped and quantified under standard assay conditions. The kinetic parameters $\left(\mathrm{K}_{\mathrm{m}}\right.$ and $\mathrm{V}_{\max }$ ) were determined from a Lineweaver-Burk plot using different concentrations ( 0 to $6 \mathrm{mM}$ ) of the substrate $p \mathrm{NP}-\alpha-\mathrm{Man}$.

\section{Analysis of the degradation products}

The eventual hydrolysis of mannobiose substrates $(1 \mathrm{mM})$ by $\alpha$-mannosidase Rplt $\mathrm{M}$ was tested with $0.45 \mu \mathrm{g}$ of enzyme mixed in $100 \mathrm{mM}$ sodium acetate buffer $(\mathrm{pH} 4.5)$ at $37^{\circ} \mathrm{C}$ for up to 24 h. Aliquots $(5 \mu \mathrm{l})$ were removed at intervals and spotted onto a TLC plate to monitor the hydrolysis of different linked disaccharides. The plate was run with butanol-acetic acid-water $(9: 3.75: 2.25, \mathrm{v} / \mathrm{v} / \mathrm{v})$ and developed with naphto-resorcinol in ethanol and $\mathrm{H}_{2} \mathrm{SO}_{4} 20 \%(\mathrm{v} / \mathrm{v})$. The sugars spots were visualized keeping the plate at $110^{\circ} \mathrm{C}$ for $5 \mathrm{~min}$.

\section{RESULTS}

\section{Enzyme purification}

Purification results for the $\alpha$-mannosidase Rplt $\mathrm{M}$ from the digestive fluid of oil palm weevil (Rhynchophorus palmarum) larvae are summarized in Table 1. The protocol involved two chromatographic steps (Fig. 1).

After precipitation in $80 \%$ ammonium sulphate, the $\alpha$-mannosidase activity resolved on a Sephacryl S-100 HR column (pooled fractions: 98 to 117; i.e. $20 \mathrm{ml}$ ) (Fig. 1A) was ultimately purified by subjecting it to anionexchange chromatography on a DEAE-Sepharose Fast Flow column. The $\alpha$-mannosidase was eluted (sharp peak) with $0.1 \mathrm{M}$ of $\mathrm{NaCl}$ (Fig. 1B) and seven $\mathrm{ml}$ fractions were pooled (fractions: 43 to 49 ). The enzyme was purified with an overall yield of $3.8 \%$ and enriched about 3.5-fold (Table 1). A single protein band was revealed by silver staining on native-PAGE (Fig. 2A).

\section{Molecular properties}

After SDS-PAGE analysis under reducing conditions, the $\alpha$-mannosidase Rplt $\mathrm{M}$ showed two protein bands estimated to be 66 and $42 \mathrm{kDa}$, respectively (Fig. 2B). The relative molecular mass of the native enzyme, as determined by gel filtration, was approximately $112 \mathrm{kDa}$.

\section{pH and temperature dependences}

The optimum values of $\mathrm{pH}$ and temperature for studying $\alpha$-mannosidase activity are presented in Table 2 . The enzyme activity was maximal at $65^{\circ} \mathrm{C}$ and a $\mathrm{pH}$ of 4.5. The best stability was observed in sodium acetate and

TABLE 1. Procedure for purifying the $\alpha$-mannosidase Rplt $\mathrm{M}$ from the digestive fluid of the larvae of the oil palm weevil (Rhynchophorus palmarum).

\begin{tabular}{lccccc}
\hline Purification step & Total protein $(\mathrm{mg})$ & Total activity (UI) & Specific activity (UI/mg) & Yield (\%) & Purification fold \\
\hline Crude extract & 86.03 & 42.24 & 0.48 & 100 & 1 \\
Ammonium sulphate (80\%) & 72.35 & 36.64 & 0.51 & 88.80 & 1.06 \\
Sephacryl S-100 HR & 17.89 & 26.43 & 1.48 & 64.00 & 3.08 \\
DEAE-Sepharose Fast Flow & 0.92 & 1.57 & 1.71 & 3.80 & 3.56 \\
\hline
\end{tabular}

${ }^{\mathrm{a}}$ One unit (UI) of Rplt $\mathrm{M}$ is the amount needed to catalyze the hydrolysis of $1 \mu \mathrm{mol}$ of $p$ NP per minute. 
(A) 1

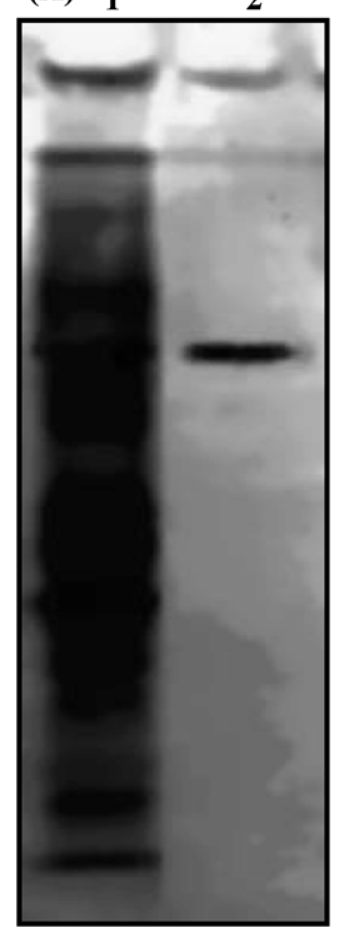

(B) 3

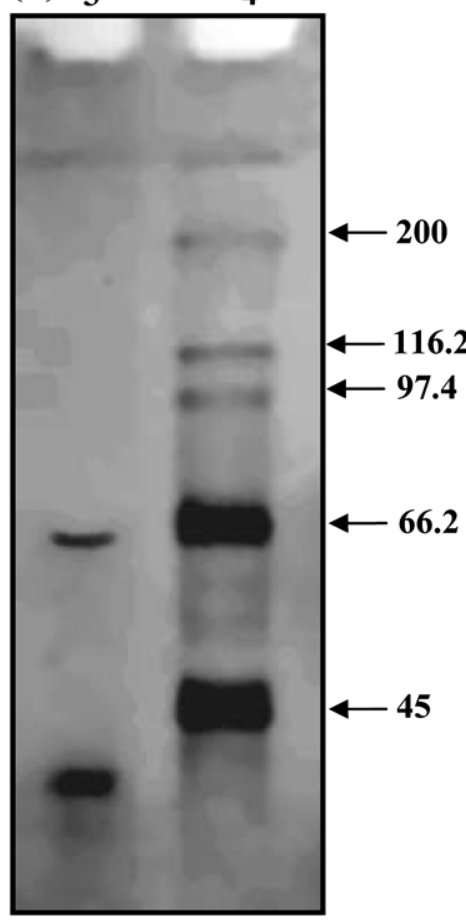

Fig. 2. PAGE analysis of $\alpha$-mannosidase Rplt $\mathrm{M}$ from the digestive fluid of oil palm weevil (Rhynchophorus palmarus) larvae. (A) Purified enzyme PAGE. (B) Purified enzyme SDSPAGE. Samples were loaded onto $7.5 \%$ gels. Lane 1, crude extract; Lanes 2 and 3, RpltM; Lane 4, standard protein molecular weight markers (values in $\mathrm{kDa}$ are indicated on the right).

sodium citrate buffers (data not shown) at a $\mathrm{pH}$ range of 4.2 to 5.0

The thermal denaturation shows that RpltM was fairly stable at temperatures up to $65^{\circ} \mathrm{C}$. At higher temperatures, thermostability decreased rapidly. However, the enzyme was not completely inactivated at $80^{\circ} \mathrm{C}$ (Fig. 3A).

The thermal inactivation study indicated that at 37 and $65^{\circ} \mathrm{C}$, in acetate buffer ( $\mathrm{pH} 4.5$ ), the $\alpha$-mannosidase remained fully stable for 150 and $25 \mathrm{~min}$, respectively (Fig. 3B). At $37^{\circ} \mathrm{C}$, the enzyme retained total activity for more than $6 \mathrm{~h}$ (data not shown). However, after $1 \mathrm{~h}$ at $65^{\circ} \mathrm{C}$, the enzyme retained $73 \%$ of its activity. After longer periods of preheating, $R p l t \mathrm{M}$ was less stable with a half-life of around $2 \mathrm{~h}$. Nevertheless, it retained almost $40 \%$ of its activity after $150 \mathrm{~min}$ (Fig. 3B).

The temperature coefficient $\left(\mathrm{Q}_{10}\right)$, calculated between 50 and $60^{\circ} \mathrm{C}$, was found to be 1.8 . From a Arrhenius plot, a value of $46.5 \mathrm{~kJ} / \mathrm{mol} / \mathrm{K}$ was obtained for the activation energy (Table 2).

\section{Effect of metal ions, chelating and reducing agents and detergents}

The effect of some chemicals on the $\alpha$-mannosidase $R p l t \mathrm{M}$ from the digestive fluid of R. palmarum larvae was examined. Most of the chemicals tested did not affect the activity of the enzyme. However, $\mathrm{Zn}^{2+}(5 \mathrm{mM})$, DTT $(1 \%$, $\mathrm{w} / \mathrm{v})$ and $\beta$-mercaptoethanol $(1 \%, \mathrm{v} / \mathrm{v})$ had a slight stimulatory effect, enhancing the activity by about $119 \%$,
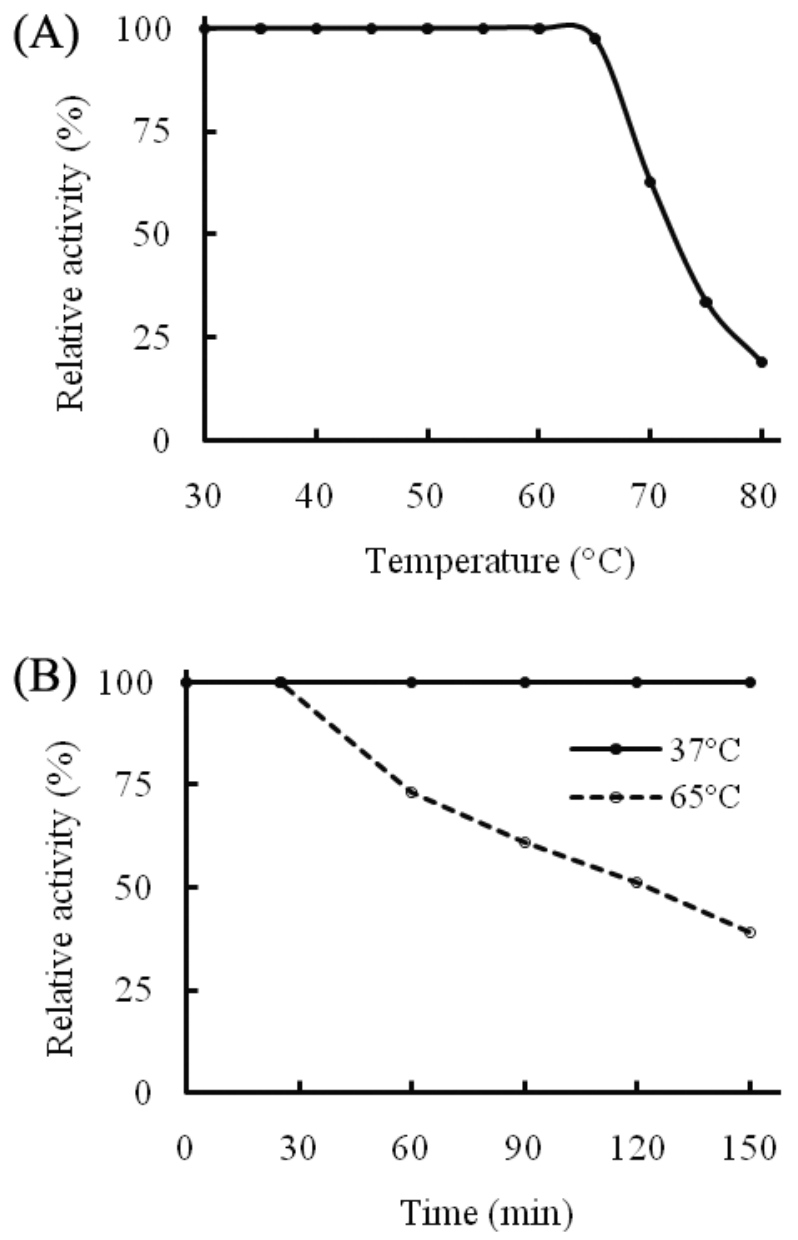

Fig. 3. Thermal stability of $\alpha$-mannosidase Rplt $\mathrm{M}$ from the digestive fluid of oil palm weevil (Rhynchophorus palmarum) larvae. (A) Thermal denaturation, the enzyme was maintained for $25 \mathrm{~min}$ at the indicated temperatures in $100 \mathrm{mM}$ sodium acetate buffer ( $\mathrm{pH} 4.5$ ). The residual activity was then measured at $37^{\circ} \mathrm{C}$ under standard assay conditions. (B) Thermal inactivation, RpltM was pre-incubated at 37 and $65^{\circ} \mathrm{C}$. At the time intervals indicated, aliquots were withdrawn and the residual activity measured at $37^{\circ} \mathrm{C}$ under standard assay conditions. The residual activity is expressed as percentage activity of zero-time control of untreated enzyme.

$109 \%$ and $110 \%$, respectively. In contrast, $\mathrm{Cu}^{2+}$, SDS and $p$ CMB acted as inhibitors (Table 2). $\mathrm{Cu}^{2+}(1 \mathrm{mM})$ and SDS $(1 \%$, w/v) completely inhibited Rplt $\mathrm{M}$ activity while $p$ CMB resulted in $20 \%$ inhibition at a concentration of $1 \%(\mathrm{w} / \mathrm{v})$.

\section{Substrate specificity and kinetic properties}

A variety of $p \mathrm{NP}$-glycosides ( $p \mathrm{NP}-\alpha$-D-Mannopyranoside, $p$ NP- $\alpha$-D-Glucopyranoside, $p$ NP- $\alpha$-L-Fucopyranoside, $p$ NP- $\alpha$-D-Galactopyranoside, $p$ NP- $\alpha$-L-Arabinopyranoside, $\quad p$ NP- $\beta$-D-Fucopyranoside, $\quad p$ NP- $\beta$-DGlucopyranoside, $p$ NP- $\beta$-D-Galactopyranoside, $p$ NP- $\beta$ D-Xylopyranoside) were tested for their suitability as substrates. The $\alpha$-mannosidase Rplt $\mathrm{M}$ had high specificity for $p \mathrm{NP}-\alpha-\mathrm{Man}$ but no activity was recorded when provided with the other $p \mathrm{NP}$-glycosides as substrates. With this substrate, the activity of the enzyme was as predicted 
TABLE 2. Physicochemical properties of $\alpha$-mannosidase Rplt $\mathrm{M}$ from the digestive fluid of oil palm weevil (Rhynchophorus palmarum) larvae. DTT, SDS and $p \mathrm{CMB}$ are the abbreviations for dithiothreitol, sodium dodecyl sulphate and para-chloromercuribenzoic acid, respectively.

\begin{tabular}{lc}
\hline Physicochemical properties & $\alpha$-mannosidase $R p l t \mathrm{M}$ \\
\hline Optimum temperature $\left({ }^{\circ} \mathrm{C}\right)$ & 65 \\
$\mathrm{Q}_{10}$ & 1.8 \\
Activation energy $(\mathrm{kJ} / \mathrm{mol} / \mathrm{K})$ & 46.5 \\
Optimum $\mathrm{pH}$ & 4.5 \\
$\mathrm{pH}$ stability & $4.2-5.0$ \\
Molecular mass/SDS-PAGE & 108 \\
Molecular mass/Gel filtration & 112 \\
$\mathrm{~K}_{\mathrm{m}}(\mathrm{mM})$ & 0.36 \\
$\mathrm{~V}_{\text {max }}(\mathrm{UI} / \mathrm{mg})$ & 1.29 \\
Activator agents & $\mathrm{Zn}^{2+}, \mathrm{DTT}, \beta$-mercaptoethanol \\
Inhibitor agents & $\mathrm{Cu}{ }^{2+}, \mathrm{SDS}, p$ CMB \\
Broad linkage specificity & $\alpha-1,2 ; \alpha-1,3$ and $\alpha-1,6$ Mannobiose \\
\hline
\end{tabular}

by the Michaelis-Menten equation. The $\mathrm{K}_{\mathrm{m}}$ and $\mathrm{V}_{\max }$ values obtained using a Lineweaver-Burk plot in the range of concentrations of $0-6.0 \mathrm{mM}$, were $0.36 \mathrm{mM}$ and $1.29 \mathrm{UI} / \mathrm{mg}$ of protein, respectively (Table 2 ).

On the other hand, the linkage specificity was investigated using different linked mannobioses (2-O- $\alpha-\mathrm{D}$ mannopyranosyl-D-mannopyranoside, 3-O- $\alpha$-D-mannopyranosyl-D-mannopyranoside and 6-O- $\alpha-\mathrm{D}-\mathrm{manno}-$ pyranosyl-D-mannopyranoside). The enzyme showed broad specificity under acidic condition, cleaving the $\alpha-1,2 ; \alpha-1,3$ and $\alpha-1,6$ Mannobioses at different rates (Fig. 4). However, its hydrolytic activity on $\alpha-1,2$ Mannobiose was greater than on $\alpha-1,3$ or $\alpha-1,6$ Mannobiose after $24 \mathrm{~h}$.

\section{Effect of $\alpha$-mannosidase specific inhibitors}

The specific inhibitory effects of the azafuranose ( $\mathrm{Sw}$ and DIM) and azapyranose (Kif and DMNJ) analogues of mannose were assayed. RpltM activity was strongly inhibited by Sw and DIM at a concentration of $10 \mu \mathrm{M}$, but both Kif and DMNJ had no inhibitory effect at the same concentration (Table 3 ).

TABLE 3. The effect of specific inhibitors on the activity of the $\alpha$-mannosidase Rplt $\mathrm{M}$ from the digestive fluid of oil palm weevil (Rhynchophorus palmarum) larvae. The relative activity is expressed as a percentage of the control without the specific inhibitor.

\begin{tabular}{lcccc}
\hline \multirow{2}{*}{ Final concentration $(\mu \mathrm{M})$} & \multicolumn{4}{c}{ Relative activity (\% of control) } \\
\cline { 2 - 5 } & Sw & DIM & Kif & DMNJ \\
\hline 0 (control) & 100 & 100 & 100 & 100 \\
0.005 & 87 & 94 & 100 & 100 \\
0.05 & 29 & 86 & 100 & 98 \\
10 & 8 & 37 & 100 & 94 \\
20 & 3 & 25 & 91 & 93 \\
\hline
\end{tabular}

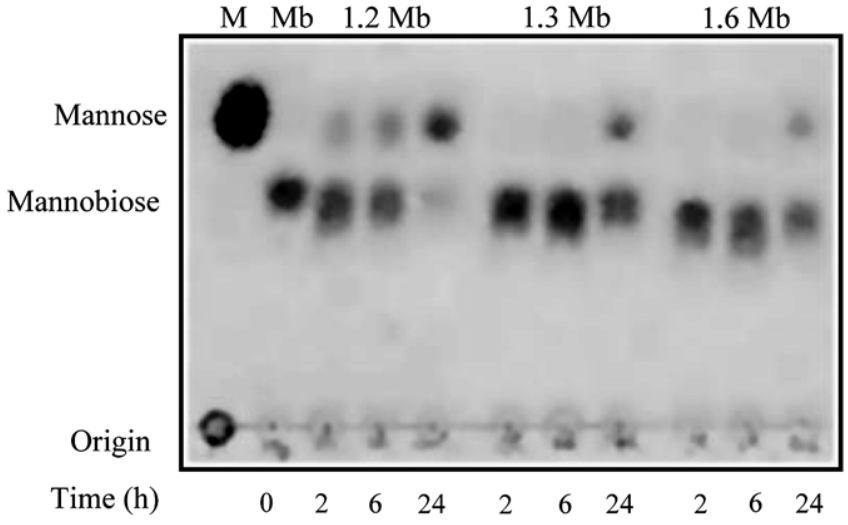

Fig. 4. TLC patterns and product distributions obtained using $\alpha$-mannosidase RpltM from the digestive fluid of oil palm weevil (Rhynchophorus palmarum) larvae to catalyze different linked mannobioses. These experiments were carried out at $37^{\circ} \mathrm{C}$ for $24 \mathrm{~h}$ using an acetate buffer $(100 \mathrm{mM}$; $\mathrm{pH} 4.5)$. At the indicated times, aliquots were removed and spotted onto the plate. Hydrolyzed products were separated using butanol-acetic acid-water $9: 3.75: 2.25(\mathrm{v} / \mathrm{v} / \mathrm{v})$ and developed using naphtoresorcinol in ethanol and $\mathrm{H}_{2} \mathrm{SO}_{4} 20 \%(\mathrm{v} / \mathrm{v})$. The sugar spots were visualized at $110^{\circ} \mathrm{C}$ for $5 \min .1,2 \mathrm{Mb}, \alpha-\mathrm{D}-\operatorname{Man} p(1,2)-\mathrm{D}$ $\operatorname{Man} p ; \quad 1,3 \quad \mathrm{Mb}, \quad \alpha-\mathrm{D}-\operatorname{Man} p(1,3)-\mathrm{D}-\operatorname{Man} p ; \quad$ 1,6 $\mathrm{Mb}$, $\alpha$-D-Man $p(1,6)-\mathrm{D}-\mathrm{Man} p$; M, mannose; Mb, mannobiose.

\section{DISCUSSION AND CONCLUSIONS}

In order to understand their physiological functions there has been a tendency to study mainly the hydrolytic activities and other properties of the digestive enzymes of insects (Ferreira et al., 1988; Terra \& Ferreira, 1994). However, no studies have been made of the $\alpha$-mannosidases of the oil palm weevil (Rhynchophorus palmarum). In this report, we describe a novel $\alpha$-mannosidase from the digestive fluid of oil palm weevil larvae, which has unusual properties. The enzyme was easily purified using the standard techniques of ammonium sulphate saturation, gel filtration and anionexchange chromatography. Using gel filtration chromatography over a Sephacryl S-100 column enabled us to separate the $\alpha$-mannosidase from other proteins, and anion-exchange chromatography on a DEAE-Sepharose Fast Flow column to remove all residual impurities. These three standard techniques were previously used to purify two $\alpha$-mannosidases from Artocarpus communis seeds (Ahi et al., 2007).

The purified enzyme has a dimeric structure with a relative molecular mass $\left(\mathrm{M}_{\mathrm{r}}\right)$ similar to those of class II $\alpha$-mannosidases, which have been assigned to the category of larger- $\mathrm{M}_{\mathrm{r}}$ rather than lower- $\mathrm{M}_{\mathrm{r}}$ (Moremen, 2000).

The $\alpha$-mannosidase Rplt $\mathrm{M}$ is not strictly specific since it released mannose from $\alpha-1,2 ; \alpha-1,3$ and $\alpha-1,6$ mannobioses. So, this enzyme is expected to be of limited interest for use in selective removal and synthesis. However, this broad spectrum $\alpha$-mannosidase would allow larvae of the palm weevil to digest oligomannosyl oligosaccharides and mannose-rich glycoproteins.

The enzyme is highly active at $\mathrm{pH} 4.5-5.0$, but is more stable at a $\mathrm{pH}$ range of 4.2-5.0. At $\mathrm{pH} 4.5$ this enzyme 
remains active and stable long enough to hydrolyze high mannose substrates. That an acidic optimum $\mathrm{pH}$ value is also reported for other $\alpha$-mannosidases from insect larvae e.g. Rhagium inquisitor and Rhynchosciara americana (Chipoulet \& Chararas, 1985; Terra \& Ferreira, 1994), which are unlike the $\alpha$-mannosidases from Drosophila melanogaster (Rabouille et al., 1999) and Spodoptera frugiperda (Jarvis et al., 1997) that require a near neutral $\mathrm{pH}$.

Rplt $\mathrm{M}$ was thermophilic being optimally active at $65^{\circ} \mathrm{C}$. Running biotechnological processes at a high temperature has many advantages. High temperature has a significant effect on bioavailability and solubility, and is accompanied by a decrease in viscosity and an increase in the diffusion coefficient of organic compounds. Consequently, higher reaction rates due to smaller boundary layers are expected (Becker et al., 1997; Niehaus et al., 1999). To the best of our knowledge, except for a few microorganisms that produce such thermophilic enzymes (Angelov et al., 2006), microbial, animal and vegetable kingdom $\alpha$-mannosidases are mostly mesophilic (Nankai et al., 2002; Misaki et al., 2003; Ahi et al., 2007). In addition, RpltM remains fully active at 37 and $65^{\circ} \mathrm{C}$ for a long time (more than $6 \mathrm{~h}$ and $25 \mathrm{~min}$, respectively) and the half-life at $65^{\circ} \mathrm{C}$ was approximately $2 \mathrm{~h}$ when the $\mathrm{pH}$ is optimum. The stability of the $\alpha$-mannosidase Rplt $\mathrm{M}$ (pH stability and thermostability) means it is suitable for use as an industrial biocatalyst (Ng \& Kenealy, 1986; Zamost et al., 1991).

The broad specificity and sensitivity to Sw and DIM largely matches the characteristics of lysosomal $\alpha$-mannosidases and bears out the link with class II $\alpha$-mannosidases (Shah et al., 2008). Due to the sensitivity of Rplt $\mathrm{M}$ to swainsonine, an anti-cancer agent, the structure of this $\alpha$-mannosidase could serve as a new model for cancer therapy development (Van den Elsen et al., 2001). The metal ion $\mathrm{Zn}^{2+}$ enhanced the activity of RpltM to about $119 \%$. Thus, this metal ion appears to be essential for this enzyme's activity. This metal ion is present at the active site of Drosophila melanogaster class II Golgi $\alpha$-mannosidase (Van den Elsen et al., 2001) and other lysosomal $\alpha$-mannosidases (Daniel et al., 1994).

In contrast, the other chemicals tested mostly had no effect, whereas $\mathrm{Cu}^{2+}$, SDS and $p \mathrm{CMB}$ completely inhibited the enzyme's activity. So, these agents should not be used in this enzyme mixture. The $\mathrm{Cu}^{2+}$ sensitivity of insect cell class II $\alpha$-mannosidases has previously been reported (Altmann \& März, 1995) as has the inhibition of other hydrolases (Faulet et al., 2006).

Finally, the present study shows that the extracellular $\alpha$-mannosidase Rplt $\mathrm{M}$ from the digestive fluid of oil palm weevil (Rhynchophorus palmarum) larvae behaved like lysosomal and class II $\alpha$-mannosidases. This enzyme is thermoacidophilic, thermostable and has a broad specific spectrum. Hence, Rplt $\mathrm{M}$ although important for digestion of food by larvae of the oil palm weevil nutrition is likely to have only qualified use in biotechnology.
ACKNOWLEDGEMENTS. This work was supported by a Ph.D. grant to the first author. The authors are grateful to Prof. J.-P. Sine (Université de Nantes, France) for his assistance.

\section{REFERENCES}

Ahi A.P., Gonnety T.J., Faulet B.M., Kouamé L.P. \& Niamké S.L. 2007: Biochemical characterization of two $\alpha$-mannosidases from breadfruit (Artocarpus communis) seeds. Afr. J. Biochem. Res. 1: 106-116.

Akama T.O., Nakagawa H., Wong N.K., Sutton-Smith M., Dell A., Nakayama J., Nishimura S., Pai A., Moremen K.W., MARTH J.D. \& FuKUDA M.N. 2006: Essential and mutually compensatory roles of $\alpha$-mannosidase II and $\alpha$-mannosidase IIx in $N$-glycan processing in vivo in mice. Proc. Natl. Acad. Sci. USA 103: 8983-8988.

Altmann F. \& März L. 1995: Processing of asparagines-linked oligosaccharides in insect cells: evidence for $\alpha$-mannosidase II. Glycoconj. J. 12: 150-155.

Angelov A., Putyrski M. \& Liebl W. 2006: Molecular and biochemical characterization of $\alpha$-glucosidase and $\alpha$-mannosidase and their clustered genes from the thermoacidophilic archaeon, Picrophilus torridus. J. Bacteriol. 188: 7123-7131.

Athanasopoulos V.I., Niranjan K. \& Rastall R.A. 2004: Regioselective synthesis of mannobiose and mannotriose by reverse hydrolysis using a novel 1,6- $\alpha$-mannosidase from Aspergillus phoenicis. J. Mol. Catal. B Enzym. 27: 215-219.

Becker B., Ramakrishnan S., Menovsky A.A., Nieuwenhuys G.J. \& Mydosh J.A. 1997: Unusual ordering behaviour single-crystal $U_{2} R h_{3} S i_{5}$. Phys. Rev. Lett. 78: 1347-1350.

Blum H., BeIER H. \& Gross B. 1987: Improved silver staining of plant proteins, RNA and DNA in polyacrylamide gels. Electrophoresis 8: 93-99.

Cenci Di Bello I., Fleet G., Namgoong S.K., Tandano K.I. \& WiNCHESTER B. 1989: Stucture-activity relationship of swainsonine. Inhibition of human $\alpha$-mannosidases by swainsonine analogs. Biochem. J. 159: 855-861.

Chipoulet J.M. \& Chararas C. 1985: Survey and electrophoretical separation of the glycosidases of Rhagium inquisitor (Coleoptera: Cerambycidae) larvae. Comp. Biochem. Physiol. (B) 80: 241-246.

Daniel P.F., Winchester B. \& Warren C.D. 1994: Mammalian alpha-mannosidases: multiple forms but a common purpose? Glycobiology 4: 551-566.

Faulet M.B., Niamké S., Gonnety T.J. \& Kouamé L.P. 2006: Purification and biochemical characteristics of a new strictly specific endoxylanase from termite Macrotermes subhyalinus workers (Macrotermitinae - Termitidae). Bull. Insectol. 59: $17-26$.

Ferreira C., Ribeiro A.F., Garcia E.S. \& Terra W.R. 1988: Digestive enzymes trapped between and associated with the double plasma membranes of Rhodnius prolixus posterior midgut cells. Insect Biochem. 18: 521-530.

Giordani R., Seipaio M., Moulin T.J. \& Regli P. 1991: Antifungal action of Carica papaya latex: isolation of fungal cell wall hydrolysing enzymes. Mycoses 34: 469-477.

Heikinheimo P., Helland R., Leiros H.K., Leiros I., Karlsen S., Evjen G., Ravelli R., Schoehn G., Ruigrok R., Tollersrud O.K., McSweeney S. \& Hough E. 2003: The structure of bovine lysosomal $\alpha$-mannosidase suggests a novel mechanism for low-pH activation. J. Mol. Biol. 327: 631-644.

Henrissat B. \& Bairoch A. 1993: New families in the classification of glycosyl hydrolases based on amino acid sequence similarities. Biochem. J. 293: 781-788. 
Henrissat B. \& Bairoch A. 1996: Updating the sequence-based classification of glycosyl hydrolases. Biochem. J. 316: 695-696.

Hirsch C., Blom D. \& Ploegh H.L. 2003: A role for $\mathrm{N}$-glycanase in the cytosolic turnover of glycoproteins. EMBO J. 22: 1036-1046.

Howard S., Braun C., McCarter J., Moremen K.W., Liao Y.Y. \& Withers S.G. 1997: Human lysosomal and Jack bean $\alpha$-mannosidases are retaining glycosidases. Biochem. Biophys. Res. Commun. 238: 896-898.

Jarvis D.L., Bohlmeyer D.A., Liao Y.F., Lomax K.K., Merkel R.K., Weinkauf C. \& Moremen K.W. 1997: Isolation and characterization of a class II alpha-mannosidase cDNA from lepidopteran insect cells. Glycobiology 7: 113-127.

KorNFELD R. \& KorNFELD S. 1985: Assembly of asparaginelinked oligosaccharides. Annu. Rev. Biochem. 54: 631-664.

LAEMMLI U.K. 1970: Cleavage of structural proteins during the assembly of the head of bacteriophage T4. Nature 227: 658-685.

Liao Y.F., Lal A. \& Moremen K.W. 1996: Cloning, expression, purification and characterization of the human broad specificity lysosomal acid $\alpha$-mannosidase. J. Biol. Chem. 271: 28348-28358.

Lowry O.H., Rosebrough N.J., Farra L. \& Randall R.J. 1951: Protein measurement with Folin-phenol reagent. J. Biol. Chem. 193: 265-275.

Maruyama Y., Nakajima T. \& Ichishima E. 1994: A 1,2-alphaD-mannosidase from a Bacillus sp.: purification, characterization and mode of action. Carbohydr. Res. 251: 89-98.

Michalski J.C., Haeuw J.F., Wieruszeski J.M., Montreuil J. \& STRECKER G. 1990: In vitro hydrolysis of oligomannosyl oligosaccharides by the lysosomal alpha-D-mannosidases. Eur. J. Biochem. 189: 369-379.

Misaki R., Fujiyama K., Yokoyama H., Ido Y., Miyauchi K., Yoshida T. \& SeKI T. 2003: Characterization of almond $\alpha$-mannosidase and its application for structure analysis of sugar chain. J. Biosci. Bioeng. 96: 187-192.

Moremen K.W. 2000: $\alpha$-Mannosidases in asparagine-linked oligosaccharide processing and catabolism. In Ernst B., Hart G. \& Sinay P. (eds): Oligosaccharides in Chemistry and Biology: A Comprehensive Handbook. Wiley \& Sons, New York, pp. 81-117.

Moremen K.W., Trimble R.B. \& Herscovics A. 1994: Glycosidases of the asparagine-linked oligosaccharide processing pathway. Glycobiology 4: 113-125.

Nankai H., Hashimoto W. \& Murata K. 2002: Molecular identification of family $38 \alpha$-mannosidase of Bacillus sp. strain
GL1, responsible for complete depolymerisation of xanthan. Appl. Environ. Microb. 68: 2731-2736.

NG T.K. \& KenEaly W.R. 1986: Industrial application of thermostable enzymes. In Brock T.D. (ed.): Thermophiles General, Molecular and Applied Microbiology. John Wiley, New York, pp. 197-205.

Niehaus F., Bertoldo C., Kähler M. \& Antranikian G. 1999: Extremophiles as a source of novel enzymes for industrial application. Appl. Microbiol. Biotechnol. 51: 711-729.

Raboullle G., Kuntz D.A., Lockyer A.E., Watson R., Signorelli T., Rose D.R., Van Der Heuvel M. \& Roberts D.B. 1999: The Drosophila GMII gene encodes a Golgi a-mannosidase II. J. Cell Sci. 112: 3319-3330.

Shah N., Kuntz D.A. \& Rose D.R. 2008: Golgi alphamannosidase II cleaves two sugars sequentially in the same catalytic site. Proc. Natl. Acad. Sci. USA 105: 9570-9575.

Sun H., Yang H. \& AsKINS M.E. 1999: Retrovirus vector mediated correction and cross correlation of lysosomal $\alpha$-mannosidase deficiency in human and feline fibroblasts. Hum. Gen. Ther. 10: 1311-1319.

Tatara Y., Lee B.R., Yoshida T., Takahashi K. \& Ichishima E. 2003: Identification of catalytic residues of $\mathrm{Ca}^{2+}$ independent 1,2- $\alpha$-D-mannosidase from Aspergillus saitoi by site-directed mutagenesis. J. Biol. Chem. 278: 25289-25294.

TERra W.R. \& Ferreira C. 1994: Insect digestive enzymes: properties, compartmentalization and function. Comp. Biochem. Physiol. (B) 109: 1-62.

Thomas B., Barbara K., Peter J.M., Øivind N., Ole K.T. \& JoHN J.H. 2001: Purification and characterization of recombinant human lysosomal $\alpha$-mannosidase. Mol. Genet. Metab. 73: $18-29$.

Tremblay L.O., Kovacs E.N., Daniels E., Wong N.K., SuttonSmith M., Morris H.R., Dell A., Marcinkiewicz E., Seidah N.G., McKerlie C. \& Herscovics A. 2007: Respiratory distress and neonatal lethality in mice lacking Golgi $\alpha-1,2$-mannosidase IB involved in N-glycan maturation. $J$. Biol. Chem. 282: 2558-2566.

Van Den Elsen J.M., Kuntz D.A. \& Rose D.R. 2001: Structure of Golgi alpha-mannosidase II: a target for inhibition of growth and metastasis of cancer cells. EMBO J. 20: 3008-3017.

VARKI A. 1993: Biological roles of oligosaccharides: all the theories are correct. Glycobiology 3: 97-130.

Zamost L.B., Nielsen K.H. \& StaRnes L.R. 1991: Thermostable enzymes for industrial applications. J. Ind. Microbiol. 8: 71-82.

Received October 17, 2008; revised and accepted January 5, 2009 